\section{DIPHTHERIA IN MANILA}

\author{
A. P. GOFF, M.D. \\ Chief, San Lazaro Hospital, Philippine Health Service \\ MANILA, P. $\mathbf{I}$.
}

During the last of September and first of October, 1915 , six patients with diphtheria were admitted to San Lazaro Hospital, with five deaths. All of these patients except the one who recovered had been sick for a week or more on admission, and all of the deaths were due to toxemia, nephritis, bronchopneumonia or some other complication.

It has been known practically since American occupation that diphtheria existed in the islands, but this little outbreak showed more cases than usual for a given period, and also, from the high mortality, a greater virulence.

The delay in getting these patients to the hospital was due, in great part, to the ignorance of the relatives or friends of the patients as to the true nature of the disease, as they thought it was simply a sore throat, or "angina," until the condition became serious.

In view of the foregoing facts, and as diphtheria has undoubtedly gradually increased in Manila during the past few years, it was thought best to take somewhat extraordinary preventive measures. Another strong factor in influencing the director and other officials of the Philippine Health Service toward taking these measures was the fact that diphtheria antitoxin was very scarce at this time, there being on hand enough for only a very few severe cases.

It was therefore decided to take specimens from the throats of schoolchildren in Manila, and from all persons in any way contacts of positive cases. It has for years been the rule to take specimens from all direct contacts, but at this time it was thought necessary to carry out operations on a more extensive scale, and in a more thorough manner. Accordingly, during the months of October and November more than 7,000 throat specimens were taken, and of these more than 600 , or about 9 per cent., were found positive for diphtheria by the Burean of Science.

The greatest number of carriers admitted to San Lazaro Hospital on any one day was 130 , October 15 , and the greatest number in hospital at any one time was 246, October 21. Two consecutive negatives on different dates were required for discharge, and the longest time any carrier was held was seventeen days, although on a former occasion one was held as long as forty days. Of the number of carriers mentioned, more than twenty, or about 4 per cent., developed symptoms of diphtheria-fever, sore throat, etc.-after entering the hospital, and received serum, the average dose for these being a little less than 3,000 units. It is believed that most of these cases which developed from carriers would have become quite severe without the early use of serum, and that several of the patients would undoubtedly have died; besides this direct saving of life it is very probable, in fact almost beyond doubt, that the preventive measures taken against diphtheria saved Manila from a more or less severe epidemic.

Diphtheria among both Americans and Filipinos is well known in Manila and the islands, and does not differ essentially from the disease as found in the United States. Antitoxin is always used freely, and almost invariably with success when the patients are brought to the hospital in fair season. One good effect of the publicity given to the antidiphtheria measures taken by the Philippine Health Service, through the great number of people examined, has been the voluntary presentation at the hospital, both from the city and from the provinces, of numerous patients in the early stages, who have all recovered. Manila is at present practically free from diphtheria; there is only one mild case in the hospital and there are no carriers.

All classes of Americans and Filipinos were among those quarantined, and the enforced imprisonment was, as a rule, undergone with patience and equanimity.

\section{STUDIES ON DIPHTHERIA}

II. THE TREATMENT OF DIPHTHERIA CARRIERS BY TONSILLECTOMY *

$$
\begin{aligned}
& \text { H. } \odot . \text { RUH, M.D., } \\
& \text { M. J. MILLER, M.D. } \\
& \text { R. G. PERKINS, M.D. } \\
& \text { CLEVELAND }
\end{aligned}
$$

In another paper ${ }^{2}$ we have given our views on some of the phases of the carrier problem in diphtheria, and have called special attention to our definition of a "carrier" and to our tentative classification of the various forms of Bacillus diphtheriae. For better understanding of the following remarks we may again state our definition of a true carrier, namely, that such a person in order to become a true carrier must harbor virulent diphtheria bacilli (in or upon the tissues) for a period of twenty-one days or more.

In the endeavor to get rid of these menaces to the health of the community, a great variety of measures have been attempted. We have tested out to our own satisfaction many of the measures advised, but have not found them worthy of routine procedure.

The methods of treatment for freeing carriers of the organisms may be divided into three classes:

\section{BIOLOGIC PRODUCTS}

Various biologic products have been used in numerous series of cases with indifferent results. The diphtheria antitoxin of course should not be considered, as it has no effect on the organism. It might be noted in passing that it is remarkable how long the idea obtains in the minds of many physicians that antitoxins can in some way affect Bacillus diphtheriae in the body. Toxin-antitoxin mixtures are also useless.

Petruschky ${ }^{2}$ seems to have been the first to use a vaccine. His results, while suggestive, are far from conclusive, and further work along this line must be done before discarding his method.

Hewlett and Nankivell" were the first to use a "vaccine" having as its active principle the "endotoxin." They prepared their vaccine from Bacillus diphtheriae by using a modification of the Macfadyen-Rowland method. Their results seem to give more promise than those of Petruschky. In a personal communication Dr. Hewlett states that he is quite certain of the effcacy of the treatment, and only awaits the opportunity for a more extended trial with the "endotoxin."

* From the Department of Hygiene, Western Reserve Medical School, the Bacteriological Laboratory of the Division of Health, and the Contagious Department of the Cleveland City Hospital.

1. Ruh, H. O.; Miller, M. J., and Perkins, R. G.: Jour. Infect. iseases, to be published.

2. Petruschky: Arb. a. d. path. Inst. zu Tübingen, 1908, vi,.Pt. ii, p. 331

3. Hewlett and Nankivell: Lancet, London, July 20, 1912, p. 143 Hewlett: Ibid., June 28, 1913. 